\title{
Ambedkarites in Making:The Process of Awakening and Conversion to Buddhism among Non-Mahar Communities in Maharashtra
}

\author{
Tushar Ghadage'
}

\begin{abstract}
Scholars have presented Buddhist discourse in Maharashtra- the western part of India, as an expression of protest and emancipation of the former untouchable caste Mahar. But in the recent past, people from different social backgrounds belonging to non-Mahar castes have embraced Buddhism. Now it has become the collective discourse of protest of different castes and tribes from marginalized communities. This paper, an outcome of my anthropological study, concerns with changing consciousness among non-Mahar castes regarding conversion to Buddhism as a tool of resistance to overcome caste inequalities. Brahmanical patriarchy is the basis on which the caste system thrives, thus it is the root of women's oppression. Women's assertion for a gender-equal society and its actual implementation on the ground constitutes a major part of the anti-caste movement. Therefore, this study also seeks the answer to the question of how Buddhism helps to rupture the caste patriarchy and its rigid structure. A significant indicator would be to see precisely how women are breaking those age-old boundaries of castes. Therefore, this paper also addresses the issue of women's emancipation through Buddhism and how it challenges the Brahmanical patriarchy and liberates its women followers from oppression.
\end{abstract}

\section{Keywords}

Caste, religion, conversion, Buddhism, Non-mahars, Matang, women emancipation

\footnotetext{
'Ph.D. Research Scholar, Centre for the Study of Social Exclusion and Inclusive Policy, University of Hyderabad, Gachibowli, Hyderabad, Telangana-500046, India

E-mail: tushar.tiss@gmail.com
}

(C) 2020 Tushar Ghadage. This is an open access article distributed under the terms of the Creative Commons Attribution License, which permits unrestricted use, distribution, and reproduction in any medium, provided the original author(s) and source are credited. 


\section{Introduction}

Caste has been studied as the central organizing principle that categorizes Indian society (Rao, 2013; Dirks, 2010). Caste system is often conceptualized as a hierarchical social system that is graded, fixed, and permanent without any possibilities of change or mobility of castes, with an ascending scale of reverence and a descending scale of contempt (Ambedkar, 2013). Therefore, people belonging to the so-called lower castes face the highest scale of contempt at the hands of the so-called upper castes. People from these low castes were regarded as 'impure and polluting' and thus, considered 'untouchables'. It has been also observed that such people who are assigned a low social status in the caste hierarchy and treated unequally within the Hindu-fold are attracted to religions that advocate social equality at least theoretically (Bandyopadhyay, 2004; Jeurgensmeyer, 2009).

Religions such as Buddhism, Sikhism, and Jainism emerged in India countering the social inequalities and discrimination prevalent in Hindu society. Religions with foreign origins such as Christianity and Islam also attracted several low caste people to escape caste discrimination (Sanal Mohan, 2015; Roberts, 2016). Thus, by providing an alternative religious philosophy, they emphasized on social equality. Dr. Ambedkar appealed to his followers to renounce Hinduism and convert to the religion that would give them dignity and equality. Nearly about one million people followed his path and converted to Buddhism. Those who converted to Buddhism majorly belonged to the Mahar ${ }^{1}$ caste (Beltz, 2004). But in the recent past, people belonging to non-Mahar castes have also converted to Buddhism.

Though Mahar is the predominant scheduled caste $(\mathrm{SC})^{2}$ that converted to Buddhism earlier, people from non-Mahar scheduled castes such as Matang ${ }^{3}$ and some of the nomadic tribes ${ }^{4}$ and Other Backward Castes $(\mathrm{OBC})^{5}$ in Maharashtra have also converted to Buddhism recently. Historically, the relationship between different castes has always been that of domination, subordination, and hostility. For many years, Buddhism in Maharashtra was equated with Mahars with terms like Mahar Buddhists being used for referring to new Buddhist converts; and Matang Buddhists to denote Buddhists converts from the Matang community. This exposes the feeling of 'us' and 'them' amongst Buddhist converts from different castes (Paik, 2011). Therefore, there is always a fear of non-assimilation of different castes into Buddhism in Maharashtra as merely casting off their Hindu religion does not give them the feeling of equality, especially when the graded inequality of caste system is deeply entrenched in the society. After all, it is not just the highest ideals but the actual living practice of a religion that is important. The highest values of equality, fraternity, and liberty should not remain merely teachings and belief systems of religion but it also should be practiced in the customs, usages, observances, rituals, and the common life of religious communities (Webster, 2002). Otherwise, it can further become an obstacle for the formation of a community of the new-Buddhists.

Existing scholarship on Buddhist conversion in Maharashtra revolves around Ambedkar's conversion movement and the subsequent conversion of people from Ambedkar's Mahar caste, the largest SC community in the state. However, not many studies have been undertaken to understand how the non-Mahar castes converted to Buddhism, and the processes involved in the constitution of their religious identity. Therefore, there is a pressing need to study the 'experience of conversion' among non-Mahar castes hailing from different social, and cultural backgrounds. This 
paper seeks to address this important socio-religious movement of non-Mahar castes in Maharashtra and also explore the intersections of different caste identities and culture of an anti-caste movement that the Dalits claim to have adopted through their conversion to Buddhism.

This paper is an outcome of my Ph.D. research. The site of my inquiry is Beed district $^{6}$ of Maharashtra, where the Buddhist conversion movement has gripped nonMahar communities. Cities are considered as hubs of the conversion movement and studies on Buddhist conversion movement in the state have treated them as sites of inquiry. Most of these studies have paid very little attention to activities happening in small pockets of rural communities. Therefore, this research looks in detail in the rural and semi-urban areas, and focuses particularly on Beed district in the most deprived Marathwada region. Using non-participative observations, semi-structured interviews, and case studies as data collection methods, I interacted with newly converted Buddhists coming from different castes, from the rural and semi-urban background.

\section{Why Conversion and Why Buddhism?}

Thorat (2002) argues that, the reasons for continuation of the practice of untouchability, discrimination, and atrocities as well as violent reaction by higher castes are to be found in the continuing belief and faith by higher castes in the sanctity of the institution of caste and untouchability. The traditional Hindu social order continues to govern the thought process and behaviour of the large majority of Hindus. The provisions in the constitutional laws are secular and equal, but the customary rules of the caste system and the institution of untouchability are based on the principle of inequality. This results in a conflict between the constitution and the traditional customary rules, norm, and values of the caste system, particularly untouchability.

People continued to follow tradition as it provides immense privilege and serves their social, political, and economic interests. When the Dalits try to seek equal access and 'assert' their rights, it often invites the anger of higher caste people in the form of atrocities and physical violence. As has been well-established that the practice of untouchability and discrimination has stemmed from religious precepts and also has religious sanction, therefore, the change in the social order from a discriminatory caste Hindu society to an equal society must also have a religious character (Ambedkar, 2004; Juergensmeyer, 2009).

According to Dr. Ambedkar, religion is an indefinite word with no fixed meaning because religion has passed through many stages. He says religion is a human projection onto the cosmos of social values concerning life and its preservation embodied in the usages, practices, observances, rites, and rituals which are to shape the behaviour of those who make up the society (Webster, 2002). Dr. Ambedkar believed that the purpose of religion is to emphasize, universalize, and spiritualize social values and bring them to the mind of the individual who is required to recognize them in all his/ her acts so that he/she may function as an approved member of society. Therefore, it is necessary to check what kind of social values a particular religion promises. Does it recognize every single person worth as human being, stands for equality, offers the benefits of liberty, and promote fraternity? These questions need to be asked not merely of the teachings and belief systems of any religion but also the customs, usages, observances, rituals, and the common life of communities owing allegiance to it. 
I quote a statement of Dr. Ambedkar which he made to the Indian Franchise Committee in 1932 (Zelliot 2005, p.5)

...the system of caste and the system of untouchability form really the steel frame of Hindu society. This division cannot easily be wiped out for the simple reason that it is not based on rational, economic, or racial grounds....the chances are that untouchability will endure far longer into the future than the optimist reformer is likely to admit on account of the fact that it is based on religious dogma... The ordinary Hindu looks upon it as part of his religion and there is no doubt that in adopting towards untouchables what is deemed to be an inhuman way of behaviour, he does so more from the sense of observing his religion than from any motive of deliberate cruelty. Based on religion, the ordinary Hindu only relaxes the rules of untouchability where he cannot observe them. He never abandons them. For abandonment of untouchability to him involves a total abandonment of the basic religious tenets of Hinduism as understood by him and the mass of Hindus...

Dr. Ambedkar found Hinduism worth abandoning given its foundation rooted in discrimination. There is no sense of equality in Hinduism. Considering others as lower or higher based on one's birth into a particular caste has religious sanction in Hinduism. In many ways Dr. Ambedkar found the desired social values of equality, human dignity, and fraternity in Buddhism. To achieve equality, human dignity and fraternity one has to essentially change their religion from Hinduism to Buddhism. I will not go in details of whether to apply the concept of religion to Buddhism or not. But as Lakshmi Narasu (2004) says if the content of religion consists of God, fear of God, or the dread of unknown, or the hankering for the unseen and the unintelligible, or the feeling for the infinite, then Buddhism is not a religion. But if by religion we mean something which inspires enthusiasm and fervor, Buddhism is certainly a religion.

Therefore, religious conversion to Buddhism can be understood as a rejection of discriminatory practices inscribed and approved by the Hindu religion and inventing their practices ${ }^{7}$, which are more inclusive and equal. Conversion to Buddhism thus, is a matter of transcended identity that is equal. Through conversion, one sees freedom from oppression as not only liberation from old social alignments but a release from old religious ideas as well. So, conversion to Buddhism is a definite move toward equality in a caste-ridden society.

\section{Buddhism among Non-Mahar Communities in Maharashtra}

Several scholars have presented the Buddhist discourse in Maharashtra as an expression of protest and emancipation of the former untouchable caste Mahars and regarded Buddhism as a religion with a universal message of brotherhood and equality (Beltz, 2005; Zelliot, 2004; Omvedt, 2003). For a long time, non-Mahar castes in Maharashtra kept at the distance from Buddhism, which predominantly remained the religion of one caste, Mahars. However, a complex phenomenon like caste can't be fought out and abolished by individual castes. It requires a larger community base. Beltz (2004) argues that caste is too complex a social phenomenon to be abolished by a small minority fighting against the majority will.

In the recent past, the Buddhist conversion movement in Maharashtra has not been restricted to only the Mahars. People belonging to other low castes and tribes have started converting to Buddhism and have demonstrated how Jotirao Phule's 
Sarvajanik Satyadharma (Public Religion of Truth) can be put into practice to achieve this unity among non-Brahmin castes oppressed by upper castes. People and organizations such as late advocate Eknath Awad through Manavi Hakka Abhiyan (Campaign for Human Rights), late Atmaram Chandane through Democratic Party of India, and late G.S. Dada Kamble through the Satyashodhak Samaj Mahasangh (SSM) worked tirelessly amongst the Matang and other marginalized communities to make them aware of their political rights, mobilize public opinion, and motivate them for conversion to Buddhism.

On October 14 2006, Awad along with thousands of his followers predominantly belonging to Matang community converted to Buddhism in a grand public conversion ceremony coinciding with the 50th anniversary of Dhammachakra Pravartan Din $^{8}$ at Deeksha Bhoomi, ${ }^{9}$ Nagpur. Similarly, Dada Kamble, under the banner of Satyashodhak Samaj Mahasangha, organized more than ten Deeksha (initiation) ceremonies at different locations wherein hundreds of Matang community people converted to Buddhism.

Other economically and socially backward and isolated groups in the state comprising nomadic and de-notified tribes are also reclaiming their histories, linking their ritualistic practices to Buddhist traditions. They too are claiming Buddhism as their past. There are community leaders like Laxman Mane who are working on the agenda of reaching out to these groups and awakening them to anti-caste ideology. Like Awad, Mane too, along with a few of his colleagues converted to Buddhism on October 14, 2006, and seven months later May 27, 2007 he organized a grand public event for his followers from de-notified tribes who converted to Buddhism in Mumbai.

The non-Aryan theory regarding Aryans as foreign invaders and the non-brahmin (lower castes) as original inhabitants as proposed by Phule was de-emphasized by Hindu nationalist forces. As a result, people belonging to middle (OBC) castes preferred to align themselves with Brahmin castes. The non-Aryan concept was restricted within untouchables and tribal communities. But in recent times OBCs in Maharashtra in general, and Beed district in particular, are trying to re-establish unity among nonBrahmin castes by claiming their ethnic and cultural past by highlighting differences of traditions been followed by Hindu upper-caste and low castes historically. The Satyashodhak OBC Parishad, a leading OBC movement founded by late Hanumant Upare and now led by his son Sandeep Upare, has played an important role in bringing OBCs into the fold of Buddhism. The organization re-emphasized the belief that $\mathrm{OBCs}$ are natives of this land and were Buddhist in the past. Therefore, conversion to Buddhism for them is reclamation of their past religion.

Hanumant Upare, however, passed on March 19, 2015 before his announced conversion date of October 14, 2016. Due to the death ofHanumant Upare, Satyashodhak OBC Parishad couldn't organize the conversion ceremony on the proposed date. Later, under the leadership of Sandeep Upare, the organization organized a Deeksha ceremony, in which Upare's entire family took to Buddhism along with their followers from the OBC community.

\section{The Process of Politicization and Actual Conversion}

After a visit to Burma (Now Myanmar) and Sri Lanka, the lack of social concerns among Bhikkus (monks) there made Dr. Ambedkar think about an active Sangha (community) which would work like an 'activist missionary' (Zelliot, 2004). Dr. 
Ambedkar imagined the Buddhist monk as a social worker who works for the benefits of society unlike a priest in Hinduism. But contrary to what Dr. Ambedkar had envisioned the Buddhist monks did not go into the community to spread Buddhism. They have not reached to the places where majority Buddhists are residing. It is evident from the fact that many of the newly Buddhist converts in the villages have never seen any monks or Bhikkus reaching out to them to teach them the principles of Buddhism. Therefore, village level community leaders and social activists have taken the responsibility of 'activist missionary' and have involved themselves in the process of reaching out to householders/ lay Buddhists and preach Buddha's eightfold path.

The process of conversion to Buddhism is conscious. It is regarded as a politicization process through which people who stayed away from Buddhism for a long time are awakened. Activists employ different approaches to initiate interaction with non-politicized communities to introduce anti-caste ideology. It is an activity in which fellow community members are informed that caste is the root cause of their problems and since caste is an integral part of Hinduism, the solution to these problems lies in conversion from Hinduism. It is also believed that Buddhism will help in improving the social condition of its followers and emancipate them.

This process of politicization is complex in the way various tactics are used in pursuit of bringing people into the fold. As told by Dr. Ambedkar (2003, W\&S Vol 17. Part I) in his speech delivered at the Bombay Presidency Mahar Conference, 'to materialize the goal of conversion it is very important to judge the public opinion of all the communities.' Dr. Ambedkar believed that public opinion judged through the meetings of each caste separately is more representative and reliable than the opinion arrived at through a common meeting of all the castes together. Carrying forward this legacy of Dr. Ambedkar, continuous efforts have been made to mobilize public opinion of conversion among marginalized castes. It is done through propagating anticaste ideologies of social reformers, primarily belonging to the same castes in which politicization is progressing. For example, among Matang community anti-caste ideas of Annabhau Sathe, Lahuji Salve, and Mukta Salve who hail from the same community have been propagated. Similarly, among Charmakars, it has been done by propagating the anti-caste ideas of Sant Ravidas. Among OBCs it has been done by invoking Jotirao Phule and Savitribai Phule, ${ }^{10}$ and their anti-caste discourse of Sarva janik Satyadharma and Satyashodhak Samaj (the truth seekers society). Thereafter highlighting linkages with anti-caste ideologies of different social reformers and with Ambedkarism they try to establish a common platform for the introduction of Buddhism.

To become a Buddhist also means one must follow the Buddha's teaching. Following the eightfold path given by Gautam Buddha is the basic expectation from Buddhists. Omvedt (2003) summarized the eightfold path of Buddha and divided it into three major sections- (i) rules for living or righteous conduct, (ii) meditation, and (iii) intellectual insights. Although a householder or lay Buddhist is considered to be capable of observing all these precepts, the major emphasis is on righteous conduct. Therefore, social activists who work in the community to spread Buddhism also emphasize upon the righteous conduct of the eightfold path in their interactions.

Social platforms such as celebrating Jayantis (birth anniversaries) of eminent personalities such as Dr. Ambedkar, Mahatma Phule, Savitribai Phule, Anna Bhau 
Sathe, Chatrapati Shahu Maharaj, among others who have inspired generations are used by social activists to spread awareness and enlighten people about the anti-caste ideology and the Buddha's teachings. It is also coupled with grand public celebrations of significant events of the anti-caste movement and Dalit resistance such as the Mahad Satyagraha ${ }^{11}$, Manusmriti Dahan Din, ${ }^{12}$ Dhammachakra Pravartan Din, etc. Through these events activists reach out to masses in a bid to educate them about the forgotten histories of their ancestors.

Even though the decision on religious conversion is a personal choice and the decision is taken in individual capacity, the actual conversion ritual is done in a grand public ceremony along with other individuals who wish to convert. Such a public display of religious conversion and assertion of their right to choose their religion is considered essential not only to counter the dominant Hindu culture but also encourage others to come forward and assert their religious views openly and convert.

\section{Reinterpreting Sarvajanik Satya Dharma and Buddhist Conversion among Non-Mahars}

It is imperative to mention Mahatma Phule's 'non-Aryan theory' here. According to this theory, all lower castes can be considered a community of the oppressed for they are exploited by upper castes in a caste society (Omvedt, 1971). Phule considered all non-Brahmin castes as oppressed communities. It is nothing but the class of oppressed castes against the class of oppressor castes. However, Dr. Ambedkar had cautioned that, it's very difficult to ally with the oppressed castes as there is graded inequality among them. That proved true as most of the middle castes aligned with upper castes and separated themselves from the then untouchable low castes. There was a pressing need for a well-organized and coordinated effort to bring these oppressed castes together and form an alliance to fight caste slavery. Buddhism seems to be playing an important role in this direction as it is offering an alternative platform for this mobilization.

The activist missionary put Phule's theory of exploitation into practice to mobilize non-Brahmin castes together. As per Phule (Cited in Omvedt, 1971), Brahmins were the exploiters whose dominant position in the caste system and religiously justified monopoly over resources and knowledge enabled them to generate enormous power. Brahmins were seen as descendants of Aryan invaders, therefore an outsider, who had divided the indigenous population through the caste system. Though Phule focused on cultural and ethnic factors and not on economic and political factors as a reason for exploitation, the activist missionary (Buddhist activists) linked cultural and ethnic factors to the economic and political problems of non-Brahmin communities. Some highlighted the exclusion of oppressed communities from the development activities of the state, while some others dwelt on the persistent caste-based violence and atrocities they face; and for some of them it is about their experience of being denied citizenship rights and other basic human rights. The conscious efforts of these activist missionaries in mobilization and politicization of communities led them to take a common path that is Buddhism. Therefore, Buddhism has now become the collective discourse of protest against caste oppression for the people coming from different 
social backgrounds. It offers a collective religious identity and has the potential to challenge caste from its roots.

The real challenge for newly converted Buddhists, however, comes after crossing the hurdle of the conversion ritual. Merely converting to Buddhism does not give them equal status, especially when caste is a system of graded inequality. Dr. Ambedkar has given certain guidelines to overcome this problem and those who convert to Buddhism are expected to follow the guidelines. One of the basic and essential expectations from the new converts is to reject Hinduism and its traditions. The second expectation is to follow Buddhist principles and lead life adhering to Buddhist values. Buddhists believe that they do not have caste. It is expected to assert their identity as Buddhists without any sense of hierarchy. Newly converted Buddhists believe in equality and humanity as their social ideas. Rationalism and atheism become the basis for Buddhist lifestyle and morality holds the place of God in Buddhism (Zelliot, 2004). But these teachings and belief systems of Buddhism also need to be tested on the customs, usages, observances, rituals, and the common life of religious communities in their everyday life. After all, it is not just the highest ideals but the actual living practice of religion that is important (Webster, 2002).

\section{Women Assertion: Confronting Caste to Reconstruct Society}

The liberation of women from all kinds of oppression was the focal point of anti-caste movement led by Mahatma Phule and Savitribai Phule. They believed that genderequal society and liberation of women from oppressive caste patriarchy is the founding stage of the annihilation of the caste system. Therefore, the best way to understand whether Buddhism is helping communities to overcome caste or not is to observe how the newly converted communities deal with their women, as they are always used as a tool to control boundaries of caste in Hinduism. Women are degraded, exploited, and treated inhumanly in a caste-ridden society. Brahmanical patriarchy is rooted in the caste system and hence the root cause of women's oppression. They face discrimination in the name of rituals, customs, traditions, etc. Women are subjected to patriarchy at various levels. They face many restrictions and control over their choices even in everyday activities resulting in exclusion of women from various walks of daily life. Dalit women are doubly oppressed, first as women they are considered as the second gender in a male-dominated society and secondly, as women from oppressed castes (Paik, 2011).

With the revival of Buddhism in Maharashtra women from the converted families have found themselves caught between two conflicting ideologies: on one side the Buddhist philosophy offers liberation to all its members from all sorts of oppression and inequalities and on the other is the deep-rooted tradition of patriarchal practices of casteist Hindu society. Therefore, it is important to see how Buddhist women are challenging those boundaries of castes because it's women's assertion and its actual implementation on the ground which poses a major threat to the caste society. It also constitutes a major part of the anti-caste Buddhist ideology. 
I present here the life stories of two common women who fought their way out of caste patriarchy and adopted Buddhism and set a role model for others to follow. With their resilient fight, they showed that Buddhism offers freedom and liberation to every individual.

Madhu (name changed) who hailed from the Matang caste before her conversion had to rebel against her parents, who still believe in Hinduism. According to tradition, she was denied higher education and forced her into marriage at an early age. Against her parents' wishes, she completed her Bachelor's degree in Nursing and started working in one of the Government Medical Colleges in Maharashtra. Notwithstanding an envious government job, Madhu's life after marriage was no different from what it was at her parents'. She was routinely subjected to domestic violence for not bearing a child. Her husband, in-laws, and parents were forcing her to permit the second marriage of her husband without divorcing him. She proposed the adoption of a child as a solution. But they neither agreed to adoption nor to divorce as she had a government job which means stable income. Thus, their decision came from interest in her earnings and not from their affection for her as an individual. Finally, Madhu obtained a divorce from her husband through the legal procedure and has adopted a daughter as a single mother.

Madhu gives credit to Dr. Ambedkar for whatever she has achieved in life. She holds caste patriarchy responsible for the torture she had undergone and does not accept it as her 'fate' as expected of Hindu women. She believes it is Dr. Ambedkar and his constitution that gave her the right to live with dignity. But caste patriarchy keeps governing the thought processes of individuals and justifies such discriminatory behaviour. It is this system of caste patriarchy that made her parents treat their children of different genders unequally. Therefore, she decided to convert to Buddhism as she believes that Buddha's Dhamma has everything she requires to lead a dignified life.

Life after conversion hasn't been easy for Madhu. Her parents were already unhappy with her over her divorce decision. In addition to this, Madhu converted to Buddhism and adopted a daughter further aggravating the situation as her parents ostracized her and severed all familial relationships with her. One needs to understand the hardship Madhu has undergone at the hands of her family and her decision to convert to Buddhism from the historical context. There was a sense of internalization and acceptance among ex-untouchable castes of their 'outcaste' status in the caste hierarchy (Fitzgerald, 1997). As mentioned earlier, most of the Buddhists in Maharashtra, though not all, belong to one single caste that is Mahar. For long, the Matangs remained distant from the conversion movement. Conversion to Buddhism was considered an act of defiance of the caste norms by the Matang community, which ostracized members who embraced Buddhism. Although Mahars faced the brunt of upper castes for breaking the caste norms and daring to convert to Buddhism, they never faced any internal opposition from their caste and blood relatives as it was a collective act of conversion of the majority of their fellow caste people. The same is not the case with Matangs as about the community is pretty much divided over the issue of conversion. 
Defying all these oppressive structures Madhu, a divorcee with no child of her own (considered taboo), has adopted a girl child post-divorce, and converted to Buddhism. She is leading her life as an empowered individual having broken all the oppressive caste and patriarchal boundaries. Satyashodhak Samaj Mahasangh, the social movement started by Dada Kamble, has played a crucial role in Madhu's journey from being an oppressed Hindu woman to a self-reliant Buddhist activist. SSM works amongst the marginalized communities politicizing them about the anti-caste discourse, awakening them to the legacy of their Buddhist past and its philosophy, and finally, motivating them to convert into Buddhism. Madhu is volunteering as the District Coordinator of SSM Women Wing of one of the districts. As Dr. Ambedkar responded to questions raised against conversion and possible isolation of untouchable castes after conversion, he said the only way to end social isolation is to establish kinship with, and get themselves incorporated into another community which is free from the spirit of caste (Ambedkar, 2016). Madhu found new friends and family in SSM as she has continued to spend time in the organization and work towards spreading Buddhism among the marginalized communities.

Durkheim's (1995) definition of religion emphasizes more on the importance of religious beliefs and practices, which are sacred. This sacred gets its meaning in connection with forbidden. Sacredness is maintained by protecting and prohibited from something which is not considered as sacred. Similarly, women's body is used by Hinduism to maintain sacredness by imposing many restrictions on women. Women were made to carry the burden of maintaining the purity of religious rituals in Hinduism. The natural capacities of menstruation and reproduction were always considered impure. Menstruating women were kept away from the day to day life and treated as untouchable by their family members. They were restricted from taking part in auspicious religious rituals. Even in the present times though it is a rule of the constitution which is governing every individual in independent India, women continue to be oppressed in the name of religious traditions and culture.

Childless women, widows, and divorcees are seldom treated with grace by orthodox believers of the religion. Women have always been treated as second class citizens irrespective of their caste locations when it comes to religious rituals. The castes and persons involved in ritualistic affairs and priesthood are regarded as the highest and purest in the caste hierarchical society that is dominated by men. Women have not been allowed to conduct any rituals in Hinduism but although their bodies are used as tools to maintain the sacredness of rituals. Therefore, disassociating the self from the gender roles prescribed by Hindu scriptures is the first step towards liberation from a caste-patriarchal society. Madhu is the quintessence of liberation in this regard. She not only defied the gender roles but also challenged the caste boundaries with her assertion of human dignity through religious conversion.

At one point in time in the early stage of Buddhist revival in Maharashtra, all rituals in Buddhism were dominated by males- Bhante ${ }^{13}$. Bhante are also known as Baudh Bhikku or Baudhacharya in Maharashtra. But during my fieldwork in Beed district, I have witnessed Buddhist weddings in which the ceremonial part was conducted by a female Baudhacharya, Ms. Manisha, the second protagonist of my 
paper. She is a social activist from Beed, and has performed many Buddhists as well as Satyashodhak weddings. Fondly called Tai (elder sister), Ms Manisha hails from an OBC community. Her husband is also a Buddhist, who had converted to Buddhism along with their leader Eknath Avad in the mass conversion event organized by Manvi Hakka Abhiyan at Dikshabhoomi, Nagpur in 2006.

Manisha Tai represents the kind of activist missionary as envisioned by Dr. Ambedkar: She is a fulltime social activist having dedicated her life for the cause of women's emancipation. By performing such religious rituals, Tai has challenged the gender roles in the religious domain. She and her husband Mr. Ashok- also a full-time social activist, are instrumental in encouraging, arranging, and performing many intercaste/religious marriages. They not only encourage and help in solemnizing intercaste marriages but also work to ensure the safety of the newly married couples after marriages as many a time the families do not accept such alliances, especially when one of the spouses is from a lower caste.

Manisha Tai considers herself as a lay woman, who is not highly educated but her self-study about Buddha's teachings and her experience of working as a social activist at grassroots level has strengthened her belief that both men and women are equal and are equally capable of changing their life-world and that gives her the strength to stand for what is right. Manisha Tai says, 'conversion to Buddhism means you consider everyone equal. But it's not true for everyone. Even among Ambedkarite Buddhists, their women are not treated equally. Many of the men even after conversion were not aware of their subtle patriarchy in their day to day life. We have to make them aware of it.' This shows the reflexive nature of anti-caste ideology that Buddhism has imparted amongst its followers.

Manisha Tai didn't stop at highlighting her key learnings from Buddhist philosophy; she implemented those learnings in her anti-caste activism through her association with social movements. She was the President of Savitribai Phule Mahila Mandal (SPMM). SPMM is one of the initiatives of Manavi Hakka Abhiyan. Creating awareness about gender equality among men and women is one of the most important activities undertaken by SPMM. It has organized multiple workshops for men and women on gender equality and developing leadership qualities among women. 'Unless we achieve gender equality in all spheres of life, we can't say that we have become Buddhists in a true sense', she says.

Dr. Ambedkar (2016, W\&S Vol.5) believed that 'the purpose of religion is not to explain the origin of the world.... An ideal religion is one that transforms society into a moral, ideal, and democratic order, such as Buddhism.' This methodology of Dr. Ambedkar clubbing Buddhist values with political activism to bring social change reflects in the kind of work these women social activists are presently engaged in. As social activists, they are using Buddhist values in their day to day activities in challenging Brahmanical patriarchal structure by rejecting gender roles and showing compassion in their approach while addressing women's issues irrespective of caste and class. 


\section{Conclusion}

Through this paper, I have tried to demonstrate that Buddhism now is not restricted to one particular Dalit caste but has become a collective form of protest for people belonging to various marginalized identities in Maharashtra. People from different social backgrounds are taking to the Buddhist way of life to assert their disapproval of the discriminatory practices of the Hindu religion. In the process, women have taken the lead and they are rejecting the dominant perception and popular notion that women are second class citizens and are always supposed to be subordinate to men. The converted Buddhist women have rejected the gender roles prescribed by the Brahmanical patriarchal caste structure and stand against any form of oppression. By converting from Hinduism, they are not washing their hands of their responsibilities, rather they draw power from the Buddhist philosophy to change their life-world. Buddhist women are at the forefront in reshaping and reconstructing their social, political, cultural, and biological conditions. As it is rightly pointed out by Omvedt (1971), what Phule seems to have sensed accurately that as long as there was inequality in the family, there could be no true equality in the society. Suppression of women, in traditional Hindu culture, went hand in hand with the suppression of low castes and untouchables. Against this backdrop, Buddhism plays an important role as it provides an alternative world view different from the oppressive caste society of Hinduism which leads to the self-transformation of Buddhist women resulting in the transformation of the society, they live in.

\section{References}

Ambedkar, B.R. (2003). Writings and speeches, Vol. 17 (Part-1). Mumbai: Government of Maharashtra, Education Department.

Ambedkar, B.R. (2004). Conversion as emancipation. New Delhi: Critical Quest.

Ambedkar, B.R. (2013). Castes in India: their mechanism, genesis, and development. New Delhi: Critical Quest.

Ambedkar, B.R. (2016). Writings and Speeches, Vol.5. Mumbai: Government of Maharashtra, Education Department.

Bandyopadhyay, S. (2004). Caste, culture, and hegemony: social domination in colonial Bengal. New Delhi: Sage Publications.

Beltz, J. (2004). Contesting caste, hierarchy, and Hinduism: Buddhist discursive practice in Maharashtra. In Jondhale, S, and Beltz, J (eds.), Reconstructing the world: B R Ambedkar and Buddhism in India. New Delhi: Oxford University Press.

Beltz, J. (2005). Mahar, Buddhist, and Dalit: religious conversion and socio-political emancipation. New Delhi: Manohar.

Chakravarti, U. (2004). Is Buddhism the Answer to Brahmanical Patriarchy? In Jondhale, S, and Beltz, J (eds.), Reconstructing the World: B R Ambedkar and Buddhism in India. New Delhi: Oxford University Press.

Dirks, N. (2010). Caste of mind: colonialism and the making of modern India. New Delhi: Permanent Black.

Durkheim, E. (1995). The elementary forms of religious life. New York: The Free Press.

Fitzgerald, T. (1997). Ambedkar Buddhism in Maharashtra. Contribution to Indian Sociology (n.s.), 31,2, 225-251. 
Juergensmeyer, M. (2009). Religious rebels in Punjab- The Ad Dharm challenge to caste. New Delhi:Navayana.

Narasu, Lakshmi P. (2004). The rationality of Buddhism. In Sharma, S. K. and Sharma, U. (Eds.), Cultural and religious heritage of India, Volume 3: Buddhism. New Delhi: Mittal Publications.

Omvedt, G. (1971). Jotirao Phule and the ideology of social revolution in India. Economic and Political Weekly, 6(37), 1969-1979.

Omvedt, G. (2003). Buddhism in India: Challenging Brahmanism and caste. New Delhi: Sage Publications.

Paik, S. (2011). Mahar-Dalit-Buddhist: The history and politics of naming in Maharashtra. Contributions to Indian Sociology, 45(2), 217-241.

Rao, A. (2013). The caste question: Dalits and politics of modern India. New Delhi: Permanent Black.

Roberts, N. (2016). To be cared for-the power of conversion and foreignness of belonging in an Indian slum. New Delhi: Navayana.

Sanal Mohan, P. (2015). Modernity of slavery: struggles against caste inequality in colonial Kerala. New Delhi: Oxford University Press.

Thorat, S. (2002). Hindu social order and human rights of Dalits. Combat Law: Oct-Nov 2002: Issue 4.

Webster, J.C.B. (2002). Religion and Dalit liberation. New Delhi: Manohar Publication.

Zelliot, E. (2004). B R Ambedkar and the search for a meaningful Buddhism. In Jondhale, S, and Beltz, J (Eds.), Reconstructing the world: B R Ambedkar and Buddhism in India. New Delhi: Oxford University Press.

Zelliot, E. (2005). Ambedkar's conversion. New Delhi: Critical Quest.

\section{Endnotes}

1 The Mahar caste is numerically the largest ex-untouchable caste in Maharashtra. They comprise almost six percent of the total state population and almost sixty percent of the total scheduled caste (SC) population of the state. Apart from Maharashtra, they have scattered presence in neighbouring states of Madhya Pradesh, Gujarat, Karnataka, and Telangana.

2 The scheduled caste (SC) is the constituional category assigned to castes considered 'untouchable' in Hindu scriptures and practices. These castes are officially regarded as socially disadvantaged for implementation of an affirmative action programme called reservation in India.

3 Matang, also known as Mang is the second-largest scheduled caste in Maharashtra. They constitute thirty percent of the total SC population in the state.

4 The Nomadic Tribes and De-notified Tribes are the people without fixed habitation and consist of about sixty million people in India, out of which about five million live in Maharashtra. There are 315 Nomadic Tribes and 198 De-notified Tribes in India. Because of their nomadic lifestyle and derogatory group attributes these tribes are stigmatized and socially isolated, and remain educationally and economically backward. They are among the most marginalized communities in India.

5 The Other Backward Class is the constitutional category of castes that are educationally and economically disadvantaged given their social status in the caste hierarchy. Primarily these are castes of artisans and peasants, who are also referred to as middle-castes.

6 Beed district is located in the Marathwada region of Maharashtra. Around eighty percent of its population resides in rural areas. Out of the total population of Beed district, 13.58 percent are SC and 11.81 percent are ST. 
7 After conversion from Hinduism to Buddhism, newly converted Buddhist are not supposed to follow Hindu traditions, rituals, religious practices and also not supposed to worship god and goddess.

8 Dhammachakra Pravartan Din is the day when Dr. Ambedkar converted to Buddhism in Nagpur on October 14, 1956 along with an estimated one million followers. This day is also called Ashok Vijaydashmi as it was on this day that Emperor Ashoka embraced Buddhism.

9 Place in Nagpur, where Dr Ambedkar converted to Buddhism. Deeksha is Sanskrit for initiation.

10 Social reformer Jotirao Phule is also called Mahatma (great soul). Along with his wife Savitribai, Phule made significant contributions toward the upliftment of downtrodden communities in Maharashtra. They were pioneers in Dalit and Women's movements which laid the foundation of the anti-caste movement in India by giving an alternative ideology to the non-Brahmin subaltern castes of the nation.

11 Mahad Satyagraha also called Chavdar Tale Satyagraha was a social movement intended to resist the inhuman practices of Hindu upper castes to prevent untouchable castes from using water of a public tank. It was a non-violent civil resistance led by Dr. Ambedkar on March 20, 1927 to allow all untouchable castes to use water from a public tank in Mahad town of Raigad district. The high point of the event was the act of drinking water from the public tank by Ambedkar and his Dalit followers. The day is also observed as Social Empowerment day in India.

12 On December 25, 1927, Dr. Ambedkar along with his followers burned the Manusmriti as a symbol of the rejection of the discriminatory Hindu scripture which is the basis of untouchability against low castes in India. Manusmriti is the ancient Hindu law code that divides the Hindu society into castes with 'graded inequality.' It regulated the day to day activities and prescribed punishments for violators of the caste code.

13 Bhante is respectable title used to address Buddhist monks which confers recognition of greatness and respect in Theravada Buddhist tradition. 